\title{
PENENTUAN TINGKAT TOLERANSI BENIH IKAN SIDAT (Anguilla bicolor) TERHADAP PENCEMARAN SURFAKTAN DETERJEN
}

\author{
Imam Taufik, Siti Subandiyah, dan Yosmaniar
}

\begin{abstract}
ABSTRAK
Penelitian bertujuan untuk mengetahui daya toleransi benih ikan sidat terhadap pengaruh letal dan subletal dari surfaktan deterjen. Penelitian dilakukan di Instalasi Riset Lingkungan Perikanan Budidaya \& Toksikologi, Cibalagung-Bogor dan Unit Pembenihan Udang Galah, Sukabumi. Wadah penelitian berupa akuarium kaca: 28 unit berukuran $40 \times 20 \times 20 \mathrm{~cm}$ dan 12 unit berukuran $70 \times 40 \times 60 \mathrm{~cm}$. Hewan uji adalah benih ikan sidat berukuran bobot 0,15 $\pm 0,008$ g/ekor, bahan uji berupa surfaktan Alkyl Sulfate $\left(\mathrm{C}_{12} \mathrm{AS}\right)$. Uji toksisitas letal menggunakan metode bioassay dalam waktu pemaparan selama 96 jam. Uji subletal dilakukan dengan memaparkan benih sidat pada konsentrasi 0,$58 ; 1,95$; dan $5,85 \mathrm{mg} / \mathrm{L}$ selama 35 hari. Hasil penelitian menunjukkan bahwa nilai $\mathrm{LC}_{50}-96$ jam surfaktan AS terhadap benih ikan sidat adalah 19,5 mg/L $(18,26-20,83 \mathrm{mg} / \mathrm{L})$. Meningkatnya konsentrasi perlakuan cenderung menyebabkan derajat sintasan ikan sidat semakin rendah dan pertumbuhan semakin tinggi, meskipun secara statistik nilai sintasan dan pertumbuhan tidak berbeda nyata $(P>0,05)$ terhadap perlakuan. Pada konsentrasi $1,59 \mathrm{mg} / \mathrm{L}$ dan $5,85 \mathrm{mg} / \mathrm{L}$ surfaktan AS dapat mengakibatkan nekrosis pada jaringan hati ikan sidat.
\end{abstract}

\begin{abstract}
Determination of tolerance level of eel fry on detergen surfactant. By: Imam Taufik, Siti Subandiyah, and Yosmaniar

The aim of this study is to know lethal and sub lethal effect of surfactant detergen on fry of eel. The study was conducted at fisheries environmental laboratory of aquaculture station in Bogor and at giant prawn breeding laboratory in Sukabumi. The size of eel fry tested was $0.15 \pm 0.008$ g/fish, and agricultural chemical was alkyl sulfate surfactant $\left(C_{12} A S\right)$. Lethal toxicity tested used bioassay method in period of 96 hour and sub lethal tested used different concentration of 0.58 , 1.95 , and $5.85 \mathrm{mg} / \mathrm{L}$ in period of 35-day. The result showed $L C_{50}-96$ hours of AS surfactant was 19.5 (18.26-20.83) $\mathrm{mg} / \mathrm{L}$, the more concentration of the surfactant, the better growth was obtained however the less survival rate, ever though it was not significantly different $(P>0.05)$. The surfactant level of $1.59 \mathrm{mg} / \mathrm{L}$ and $5.85 \mathrm{mg} / \mathrm{L}$ would cause a necrosis to eel lever.
\end{abstract}

KEYWORDS: alkyl sulfate (AS), eel, tolerance, toxicity

\section{PENDAHULUAN}

Indonesia merupakan negara yang sangat potensial bagi pengembangan budi daya ikan sidat (Anguila sp.) karena terdapat sekitar 13 spesies dan sub spesies ikan sidat yang hidup di perairan Indonesia (Nontji, 1987). Kenyataan ini menunjukkan bahwa ikan sidat lokal bila dibudidayakan dapat menjadi andalan sebagai ladang usaha dan sumber protein bagi masyarakat.

Pengusaha perikanan di Indonesia dewasa ini sudah mulai merintis usaha budi daya ikan sidat baik secara ekstensif maupun intensif. Kebutuhan benih untuk kegiatan tersebut sepenuhnya masih tergantung dari hasil tangkapan di alam karena sejauh ini ikan sidat belum dapat dibenihkan secara terkontrol. Oleh karena itu, sumber benih ikan sidat di alam perlu dipertahankan dengan jalan menjaga kelestarian habitatnya, sehingga dapat memenuhi kebutuhan benih untuk budi daya secara berkesinambungan.

Faktor eksternal yang dapat mengancam kelestarian benih ikan sidat di alam adalah rusaknya habitat karena tercemar oleh limbah. Kartz (1971) dan Owen (1975) mengelompokkan limbah menjadi empat golongan utama, yaitu limbah domestik, pertanian, industri, dan radioaktif. Limbah yang seringkali mencemari perairan umum (danau dan sungai) adalah limbah domestik atau rumah tangga, dan deterjen merupakan komponen utama dalam limbah domestik.

Deterjen merupakan suatu bahan yang berbentuk serbuk atau krim yang dibuat dari bahan pembersih

Peneliti pada Balai Riset Perikanan Budidaya Air Tawar, Bogor 
sintetik (yang terdiri atas rantai karbon $\mathrm{C}_{7}-\mathrm{C}_{16}$ dengan gugus hidrofilik) dengan tambahan unsur lain. Pada umumnya deterjen tersusun atas bahan aktif yang berupa surfaktan, bahan pembangun, dan bahan tambahan. Kandungan surfaktan yang terdapat dalam deterjen sebesar 15\%-25\% (Kent, 1992).

Tercemarnya perairan oleh deterjen selain dapat bersifat letal (mematikan) juga dapat bersifat subletal. Pengaruh subletal yang diakibatkan oleh surfaktan terhadap ikan adalah rusaknya organ kemoreseptor, perubahan pola makan, serta tingkat sintasan larva dan benih yang rendah (Abel, 1974). Lebih jauh lagi, pengaruh subletal dari deterjen dikhawatirkan dapat terakumulasi di dalam tubuh ikan sidat sehingga akan menurunkan kualitasnya. Hal ini menjadi sangat penting karena ikan sidat lokal selain merupakan sumber protein bagi masyarakat, juga diorientasikan sebagai komoditas ekspor di mana untuk mencapai sasaran tersebut, kualitas produk harus terbebas dari cemaran agar dapat mendapat sertifikasi ISO-14001. Sehubungan dengan hal tersebut maka penelitian dilakukan dengan tujuan untuk mengetahui toleransi benih ikan sidat terhadap surfaktan Alkyl sulfate (AS) sebagai bahan acuan bagi pengelolaan lingkungan budi daya ikan sidat lokal.

\section{METODE PENELITIAN}

Penelitian dilakukan dalam skala laboratorium di Instalasi Riset Lingkungan Perikanan Budidaya dan Toksikologi, Cibalagung-Bogor dan Unit Pembenihan Udang Galah, Cisolok-Sukabumi. Wadah penelitian berupa akuarium kaca yang dilengkapi saluran pelimpahan air serta aerasi dan ditempatkan dalam ruangan.

Hewan uji yang digunakan adalah benih ikan sidat lokal (Anguila bicolor) dengan ukuran bobot rata-rata $0,15 \pm 0,008$ g/ekor, yang merupakan hasil tangkapan dari perairan muara Sungai Cimandiri, Kabupaten Sukabumi. Benih yang terkumpul terlebih dahulu diadaptasikan selama satu minggu dalam kondisi tempat percobaan dengan diberi makanan berupa cacing tubifex hidup. Selama masa adaptasi, kesehatan/vitalitas benih diamati dan apabila mortalitas populasi lebih dari $10 \%$ maka populasi ikan sidat diganti karena dianggap tidak layak sebagai hewan uji. Bahan uji yang digunakan adalah bahan aktif pembuat deterjen, yaitu surfaktan Alkyl Sulfate $\left(C_{12} A S\right)$.

\section{Uji Ambang Batas (Range Finding Test)}

Uji ambang batas dilakukan untuk menentukan konsentrasi letal ambang bawah ( $\left.\mathrm{LC}_{0}-48 \mathrm{jam}\right)$ dan ambang atas $\left(\mathrm{LC}_{100}-24 \mathrm{jam}\right)$, yaitu dengan cara mendedahkan hewan uji masing-masing sebanyak 10 ekor dalam bahan uji (surfaktan AS) dengan berbagai konsentrasi, yaitu: $0 ; 0,5 ; 1 ; 5 ; 9 ; 21$; dan $35 \mathrm{mg} / \mathrm{L}$, masing-masing konsentrasi diulang sebanyak 3 kali. Wadah yang digunakan berupa akuarium kaca berukuran $40 \times 20 \times 20 \mathrm{~cm}^{3}(\mathrm{p} \times \mid \times \mathrm{t})$ dengan volume air sebanyak $10 \mathrm{~L}$. Setelah diketahui nilai kisaran ambang bawah dan ambang atas maka konsentrasi dipilih dalam interval geometris, yang diperoleh dengan rumus sebagai berikut:

$$
\log N / n=k(\log a / n)
$$

\section{Keterangan:}

$N=$ konsentrasi ambang atas

$n$ = konsentrasiambang bawah

$k=$ jumlah interval konsentrasi yang diuji

$a=$ konsentrasi terkecil dalam deret konsentrasi yang ditentukan

$$
a / n=b / a=c / b=d / c=e / d=N / e
$$

Dengan rumus (1) dapat dihitung nilai konsentrasi a, selanjutnya dapat ditentukan konsentrasi b, c, d, dan e dengan menggunakan rumus (2).

\section{Uji Toksisitas}

Uji toksisitas dilakukan untuk menentukan konsentrasi letal dan subletal dari bahan surfaktan AS terhadap benih ikan sidat.

\section{Toksisitas Letal}

Dari persamaan interval geometris di atas (persamaan 1 dan 2) ditentukan 7 tingkat konsentrasi surfaktan deterjen AS yang akan digunakan dalam uji toksisitas letal. Konsentrasi tersebut berada antara ambang bawah ( $\left.\mathrm{LC}_{0}-48 \mathrm{jam}\right)$ dan ambang atas $\left(\mathrm{LC}_{100}{ }^{-}\right.$ 24 jam) yang nilainya berturut-turut adalah: 12,$5 ; 14,7$; 17,$4 ; 20,6 ; 24,3 ; 28,6$; dan $33,7 \mathrm{mg} / \mathrm{L}$.

Dalam setiap konsentrasi uji didedahkan 10 ekor hewan uji dan masing-masing diulang sebanyak 3 kali. Data mortalitas hewan uji untuk setiap konsentrasi perlakuan dicatat setelah waktu pemaparan 24,48 , 72 , dan 96 jam, kemudian dilakukan analisa probit (Litchfield \& Wilcoxon, 1949) untuk menentukan nilai $\mathrm{LC}_{50}$ pada setiap waktu pemaparan. Nilai $\mathrm{LC}_{50}-96 \mathrm{jam}$ yang diperoleh akan digunakan sebagai dasar dalam menentukan konsentrasi perlakuan pada uji toksisitas subletal.

Wadah yang digunakan berupa akuarium kaca berukuran $40 \times 20 \times 20 \mathrm{~cm}^{3}(\mathrm{p} \times \mathrm{I} \times \mathrm{t})$ dengan volume air sebanyak $10 \mathrm{~L}$. Setiap wadah dilengkapi dengan saluran pemasukan dan pelimpahan air, aerasi dan tutup berpori (kasa). 


\section{Toksisitas Subletal}

Pada uji toksisitas subletal digunakan konsentrasi perlakuan sebesar: $3 \% ; 10 \% ; 30 \%$; dari nilai $\mathrm{LC}_{50}-96$ jam dan kontrol sebagai pembanding. Konsentrasi tersebut berturut-turur adalah: 0,$58 ; 1,95$; dan 5,85 $\mathrm{mg} / \mathrm{L}$ surfaktan AS. Setiap perlakuan diulang sebanyak 3 kali dengan pemaparan selama 35 hari

Hewan uji dipelihara dengan kepadatan sebanyak 2 ekor/L atau $0,3 \mathrm{~g} / \mathrm{L}$. Wadah penelitian terdiri atas 12 unit akuarium kaca yang masing-masing berukuran $70 \times 40 \times 60 \mathrm{~cm}^{3}(\mathrm{p} \times \mathrm{|} \times \mathrm{t})$ dan diisi air dengan volume $60 \mathrm{~L}$, dilengkapi dengan aerasi dan tutup berpori (kasa). Setiap tiga unit wadah dalam masing-masing perlakuan dilengkapi dengan satu wadah penampungan untuk mempermudah saat dilakukan pergantian air.

Selama pemaparan, hewan uji diberi makanan cacing tubifex segar secara at satiation dan air media diganti setiap 24 jam dengan konsentrasi bahan uji yang sama untuk masing-masing perlakuan.

\section{Parameter}

Untuk mengetahui toleransi benih ikan sidat terhadap surfaktan AS, maka dilakukan pengujian subletal dengan mengukur pengaruhnya terhadap beberapa parameter, seperti:

\section{Sintasan (SR)}

Nilai sintasan merupakan persentase dari perbandingan antara jumlah hewan uji yang hidup pada waktu sampling dengan jumlah hewan uji yang ditebar pada awal penelitian (Effendi, 1979) dengan persamaan sebagai berikut:

$$
\mathrm{SR}=\frac{\sum \text { ikan yang hidup (ekor) }}{\sum \text { ikan yang ditebar (ekor) }} \times 100 \%
$$

\section{Laju pertumbuhan (SGR)}

Pertumbuhan hewan uji dihitung berdasarkan persentase pertambahan bobot ikan selama penelitian dalam satuan waktu. Untuk menghitung pertumbuhan digunakan rumus Ricker (1975) sebagai berikut:

$$
S G R=\left(\ln W t-\ln W_{0}\right) / D t \times 100 \%
$$

Keterangan:

$S G R=$ laju pertumbuhan harian individu (\%)

$W t=$ bobot akhir hewan uji setelah waktu $\mathrm{t}(\mathrm{g})$

$W_{0}=$ bobot awal $(\mathrm{g})$

$t \quad=$ waktu pemeliharaan (hari)

\section{Kerusakan jaringan}

Untuk mengetahui tingkat kerusakan jaringan pada organ ikan yang telah dipaparkan selama 35 hari dalam larutan surfaktan AS pada konsentrasi subletal, maka dilakukan pengamatan mikroanatomi yaitu dengan cara membuat preparasi/sediaan histologi dari organ hati. Pembuatan sediaan histologi dilakukan dengan metode Bell \& Lightner (1988) yang telah dimodifikasi dan pengamatan dilakukan menggunakan mikroskop dengan perbesaran 400 kali.

\section{Kualitas air}

Selama uji toksisitas subletal dilakukan pengukuran terhadap parameter fisika-kimia air setiap 2 hari waktu pemaparan sebelum pergantian air dilakukan. Parameter tersebut meliputi: suhu air $\left({ }^{\circ} \mathrm{C}\right)$; oksigen terlarut $(\mathrm{mg} / \mathrm{L})$; kesadahan $\left(\mathrm{mg} / \mathrm{L} \mathrm{CaCO}_{3}\right)$; $\mathrm{pH} ; \mathrm{NH}_{3}-\mathrm{N} ; \mathrm{NO}_{2}-\mathrm{N}$; alkalinitas.

\section{HASIL DAN BAHASAN}

\section{Uji ambang batas (Range finding test)}

Dari uji yang dilakukan diperoleh nilai ambang bawah ( $\mathrm{LC}_{0}-48 \mathrm{jam}$ ) dari surfaktan AS adalah $9 \mathrm{mg} / \mathrm{L}$ dan nilai ambang atas ( $\mathrm{LC}_{100}-24 \mathrm{jam}$ ) sebesar $35 \mathrm{mg} /$ L. Di antara nilai ambang bawah dan ambang atas tersebut kemudian ditentukan 7 deret konsentrasi surfaktan AS (persamaan 1 dan 2) yang akan digunakan dalam uji toksisitas letal yaitu: 12,$5 ; 14,7$; 17,$4 ; 20,6 ; 24,3 ; 28,6$; dan 33,7 mg/L.

\section{Uji Toksisitas}

\section{Toksisitas letal}

Secara kuantitaif pengaruh letal (akut) dapat didefinisikan sebagai pengaruh (respon) yang terjadi pada saat zat-zat fisika atau kimia mengganggu proses sel atau subsel dalam mahluk hidup sampai suatu batas proses kematian yang mengikutinya secara langsung. Dalam kasus yang parah, pengaruh tersebut mungkin dalam bentuk penyempitan saluran pernafasan (tercekik) atau tidak dapat bernafas, gangguan pergerakan untuk mendapatkan makanan atau untuk lari dari pemangsaan atau rusaknya habitat (Connel \& Miller, 1995).

Berdasarkan data mortalitas ikan pada setiap konsentrasi perlakuan yang dianalisis dengan metode Litchfield \& Wilcoxon (1949), ternyata konsentrasi surfaktan AS yang menyebabkan mortalitas ikan sebanyak $50 \%$ dari populasi dalam waktu pemaparan $24,48,72$, dan 96 jam berturut-turut adalah 20,7 $(18,9-22,6) \mathrm{mg} / \mathrm{L} ; 20,6(19,4-21,8) \mathrm{mg} / \mathrm{L} ; 19,8$ $(18,6-21,0) \mathrm{mg} / \mathrm{L} ;$ dan $19,5(18,3-20,8) \mathrm{mg} / \mathrm{L}$. Hal 
ini mengindikasikan bahwa toksisitas surfaktan AS terhadap ikan sidat semakin meningkat dengan bertambahnya waktu pemaparan. Menurut Bathe et al. (1974) dan Koesoemadinata (1982) bahan toksik dengan nilai $\mathrm{LC}_{50}-96$ jam sebesar $19,5 \mathrm{mg} / \mathrm{L}$ (antara $10-100 \mathrm{mg} / \mathrm{L}$ ) termasuk katagori mempunyai daya racun sedang (Moderately toxic) dengan klasifikasi golongan $\mathrm{C}$.

Ikan sidat yang dipaparkan dalam larutan surfaktan AS dosis tinggi akan memacu respirasi sebagai upaya untuk mempertahankan kondisi homeostasi sehingga mengakibatkan meningkatnya frekuensi bukaan operkulum insang. Menurut Metelev et al. (1971), konsentrasi deterjen yang cukup tinggi dapat menyebabkan peningkatan frekuensi pernafasan sampai tiga kali dari keadaan normal. Dengan meningkatnya frekuensi pernafasan, operkulum insang akan semakin sering terbuka sehingga akan lebih sering kontak dengan air yang mengandung surfaktan AS. Selanjutnya akan terjadi kerusakan sistem respirasi pada epitelium insang, sehingga ikan akan kehilangan keseimbangan, sukar bernafas, dan akan mati dengan mulut terbuka, epitelium insang membengkak dan tubuhnya tertutup lendir (Maeiw, 1971).

Nilai $\mathrm{LC}_{50}$-96 jam surfaktan AS terhadap benih ikan sidat hampir sama dengan nilai $\mathrm{LC}_{50}-96$ jam dari surfaktan AS terhadap benih ikan mas, yaitu 19,21 $\mathrm{mg} / \mathrm{L}$ (Nugraha, 2001). Hal ini menunjukkan bahwa toleransi benih ikan sidat terhadap toksisitas letal surfaktan AS setara dengan toleransi benih ikan mas terhadap bahan serupa (surfaktan AS).

Berdasarkan uji toksisitas letal dapat ditentukan nilai ambang konsentrasi aman (safety concentration) dari surfaktan AS terhadap ikan sidat yaitu sebesar
$0,975 \mathrm{mg} / \mathrm{L}$. Nilai tersebut diturunkan dari nilai $\mathrm{LC}_{50}{ }^{-}$ 96 jam yang dikalikan dengan AF (application factor) yaitu 0,05 untuk bahan yang tidak persisten (Mayer et al., 1986 dalam Pong-Masak, 2003).

\section{Toksisitas subletal}

Pengaruh subletal/kronis adalah pengaruh yang merusak bagian fisiologis atau perilaku tetapi tidak menyebabkan kematian secara langsung meskipun dapat terjadi karena gangguan terhadap proses makan, pertumbuhan atau perilaku tidak normal (Connel \& Miller, 1995). Beberapa ciri utama keadaan subletal ikan yang terkena polutan adalah kehilangan keseimbangan tubuh, mengalami perdarahan pada branchia atau beberapa baris pinnae, kanibalisme, beringas atau bahkan tubuh menjadi lemah (Tanjung, 1982).

Uji toksisitas subletal dilakukan selama 35 hari pemaparan dengan menggunakan konsentrasi surfaktan AS sebesar $3 \%, 10 \%$, dan $30 \%$ dari nilai $\mathrm{LC}_{50}-96$ jam yaitu: 0,$58 ; 1,95$; dan $5,85 \mathrm{mg} / \mathrm{L}$ dengan kontrol (tanpa surfaktan AS) sebagai pembanding. Parameter yang diamati meliputi derajat sintasan (\%), laju pertumbuhan, kerusakan jaringan hati, dan sifat fisika-kimia air.

\section{Sintasan}

Sintasan merupakan perbandingan antara jumlah ikan yang ditebar pada awal penelitian dengan jumlah ikan yang hidup pada hari ke-35 dan dinyatakan dalam persen (\%). Hasil penelitian menunjukkan bahwa semakin tinggi konsentrasi surfaktan AS akan menyebabkan sintasan ikan sidat yang semakin rendah. Sintasan paling tinggi diperoleh pada kontrol yaitu sebesar $81,9 \% \pm 8,7 \%$ disusul oleh perlakuan $0,58 \mathrm{mg} / \mathrm{L}(80,8 \% \pm 6,3 \%)$, kemudian $1,95 \mathrm{mg} / \mathrm{L}$

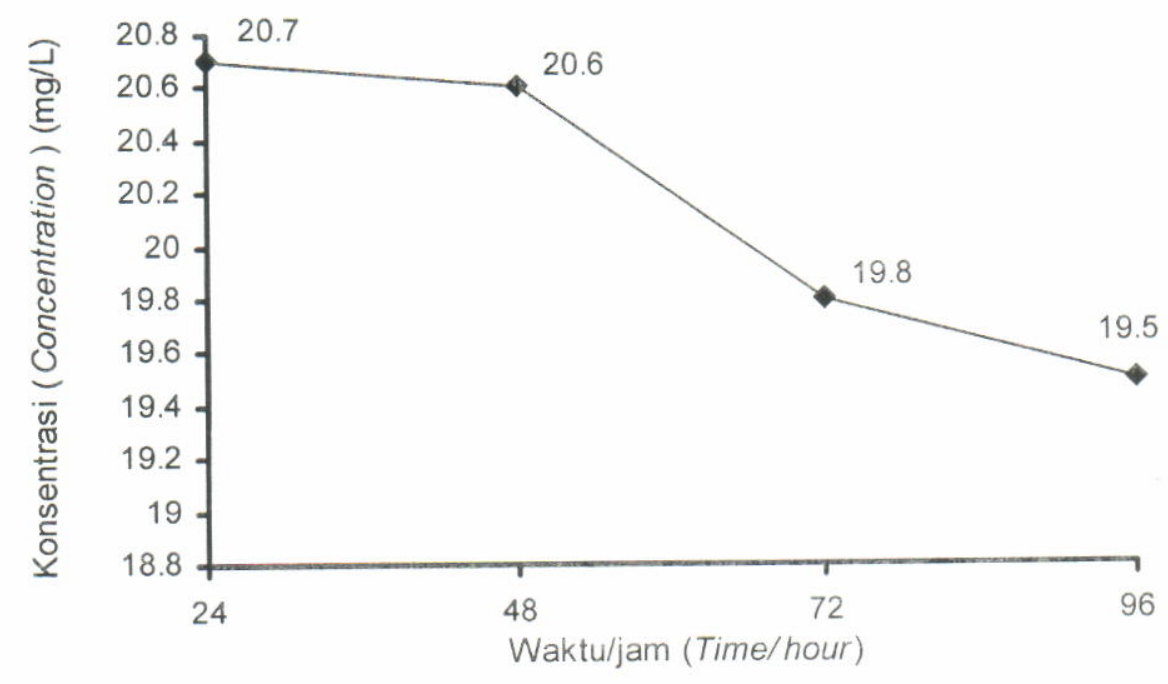

Gambar 1. Grafik nilai LC ${ }_{50}$ surfaktan AS terhadap benih ikan sidat pada setiap waktu pemaparan

Figure 1. Graphic of $L C_{50}$ of surfactant to eel fry on every exposure time 
$(80,3 \% \pm 8,2 \%)$ dan yang paling rendah pada perlakuan 5,85 mg/L $(69,5 \% \pm 6,2 \%)$ (Gambar 2).

Mortalitas ikan sidat pada kontrol serta pada konsentrasi $0,58 \mathrm{mg} / \mathrm{L}$ dan $1,95 \mathrm{mg} / \mathrm{L}$ terutama disebabkan oleh ketidakmampuan individu dalam beradaptasi dengan faktor abiotik lingkungan pemeliharaan (fisika: suhu, penyinaran, densitas, tekanan, kekeruhan; dan kimia: $\mathrm{pH}$, salinitas, oksigen terlarut, karbondioksida, amonia, alkalinitas) di mana kemampuan individu untuk mentolerir variabel lingkungan ini erat kaitannya dengan faktor genetik dan sejarah hidup sebelumnya (Affandi \& Tang, 2002).

Pada konsentrasi perlakuan sebesar $5,85 \mathrm{mg} / \mathrm{L}$ mortalitas ikan diduga lebih disebabkan oleh terjadinya bioakumulasi surfaktan AS akibat penyerapan secara difusi melalui lamela insang. Hal ini menyebabkan lamela insang yang memiliki jaringan kapiler darah untuk menangkap oksigen yang masuk cenderung bersatu dan menebal (Wilbert, 1971) sehingga proses pertukaran gas antara lamela insang dan air akan terhambat, akibatnya oksigen yang masuk ke dalam tubuh melalui sistem peredaran darah akan berkurang. Rendahnya oksigen dalam darah akan mengganggu proses metabolisme tubuh dan karena berlangsung dalam waktu yang cukup lama maka telah menyebabkan kematian. Selain itu, mortalitas juga diakibatkan oleh toksisitas surfaktan AS pada konsentrasi 5,85 mg/L melebihi kemampuan hati ikan sidat untuk menetralisir dan membuang racun sehingga terjadi degradasi fungsi hati yang berdampak kematian.

\section{Pertumbuhan}

Pertumbuhan dapat dirumuskan sebagai pertambahan ukuran panjang atau bobot dalam suatu waktu akibat pembelahan sel secara mitosis. Hal ini dapat terjadi apabila ada kelebihan input energi dan asam amino (protein) yang berasal dari makanan (Effendie, 2002). Dari hasil sampling yang dilakukan ternyata ikan sidat yang dipaparkan dalam setiap konsentrasi perlakuan surfaktan AS mengalami pertumbuhan, ditandai dengan adanya pertambahan bobot individu pada setiap waktu pengukuran (Gambar 3).

Laju pertumbuhan spesifik (SGR) ikan sidat paling tinggi dicapai pada kontrol $(4,19 \% \pm 0,51 \%)$ disusul oleh perlakuan konsentrasi $5,85 \mathrm{mg} / \mathrm{L}$ surfaktan AS $(4,08 \% \pm 0,03 \%)$, kemudian $1,95 \mathrm{mg} / \mathrm{L}(3,92 \% \pm$ $0,22 \%$ ), dan yang paling rendah pada konsentrasi 0,58 $\mathrm{mg} / \mathrm{L}$ surfaktan AS yaitu 3,85\% $\pm 0,26 \%$. Data ini mengindikasikan adanya kecenderungan bahwa semakin tinggi konsentrasi perlakuan akan memberikan persentase pertumbuhan individu yang semakin besar, meski lebih rendah dibanding kontrol. Tetapi secara statistik nilai pertumbuhan ikan uji tidak berbeda nyata $(P>0,05)$ terhadap perlakuan

Semakin tinggi persentase pertumbuhan ikan dengan bertambahnya konsentrasi surfaktan AS, menurut Huet (1987), disebabkan pada konsentrasi tertentu bahan-bahan kimia atau polutan yang dikontaminasikan pada ikan dapat menstimulasi kelenjar tiroid di mana kelenjar ini berhubungan dengan pertumbuhan. Hal serupa ditemukan pula pada hasil penelitian Belanger et al. (1995) yang menunjukkan bahwa surfaktan AS memberikan respon yang positif terhadap pertumbuhan Oligochaeta pada konsentrasi 224-1586 mg/L AS dan pertumbuhan gastropoda jenis Ferrisea (Limpet) dan Physilla (siput) pada konsentrasi $582-1586 \mathrm{mg} / \mathrm{L}$ AS pada masa pemeliharaan 8 minggu.

\section{Kerusakan Jaringan}

Pengamatan kerusakan jaringan dilakukan secara deskriptif terhadap preparasi histologi hati dari ikan

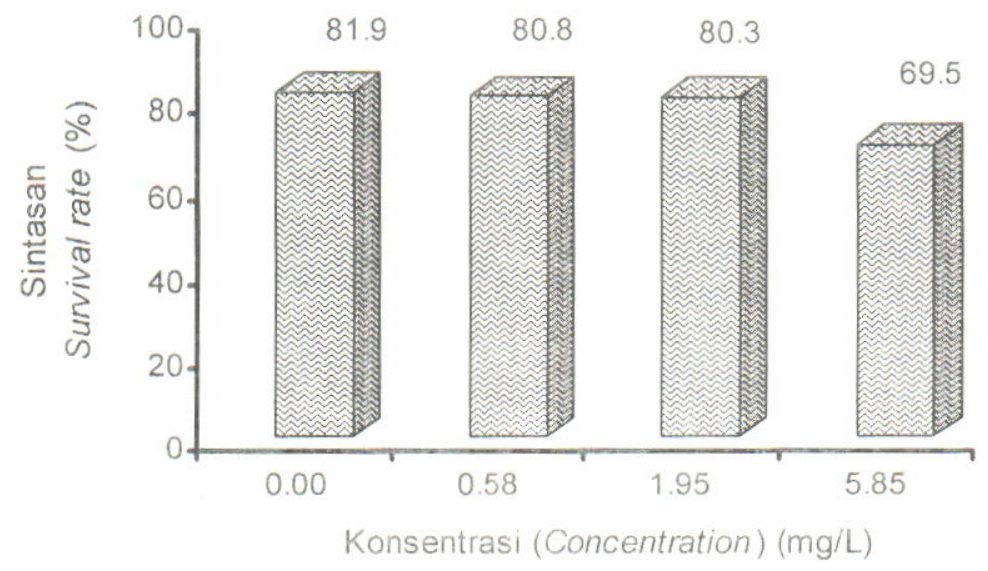

Gambar 2. Grafik sintasan ikan sidat setelah 35 hari pemaparan pada setiap konsentrasi perlakuan

Figure 2. Graphic of fry survival rate after 35 exposure-days in each treatment 


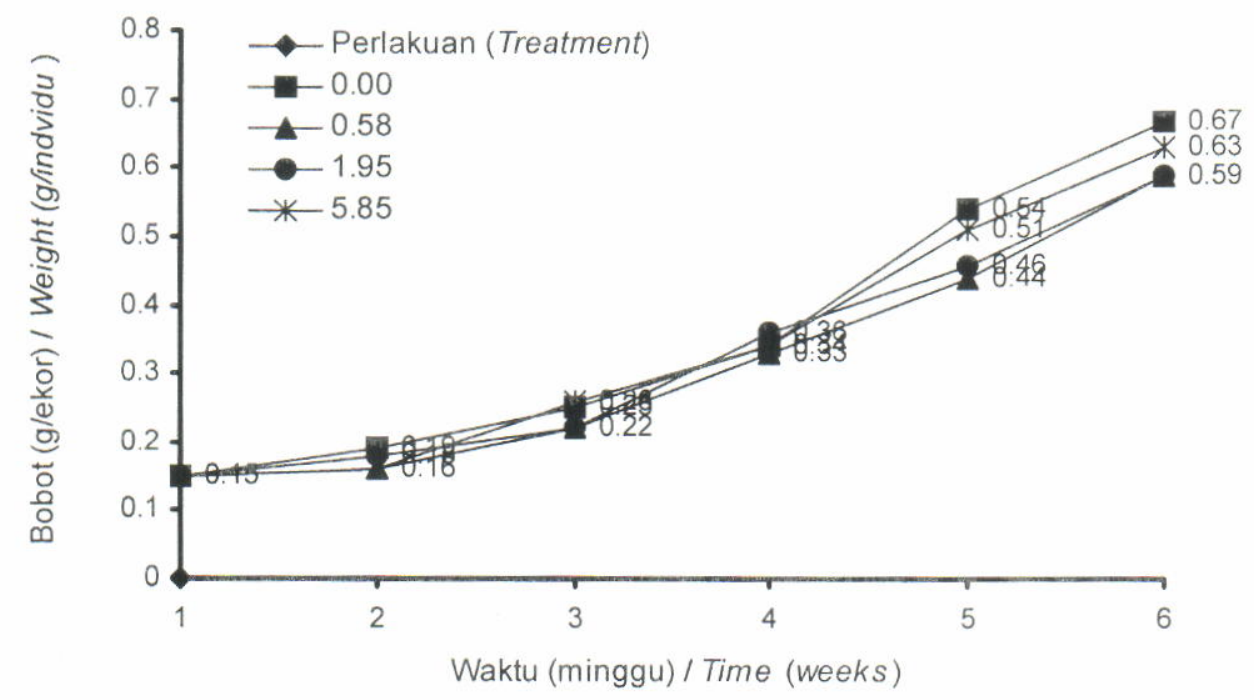

Gambar 3. Grafik pertambahan bobot individu rata-rata benih ikan sidat setiap minggu pada masing-masing konsentrasi perlakuan

Figure 3. Graphic of individual weight gain fry in each treatment

4.19

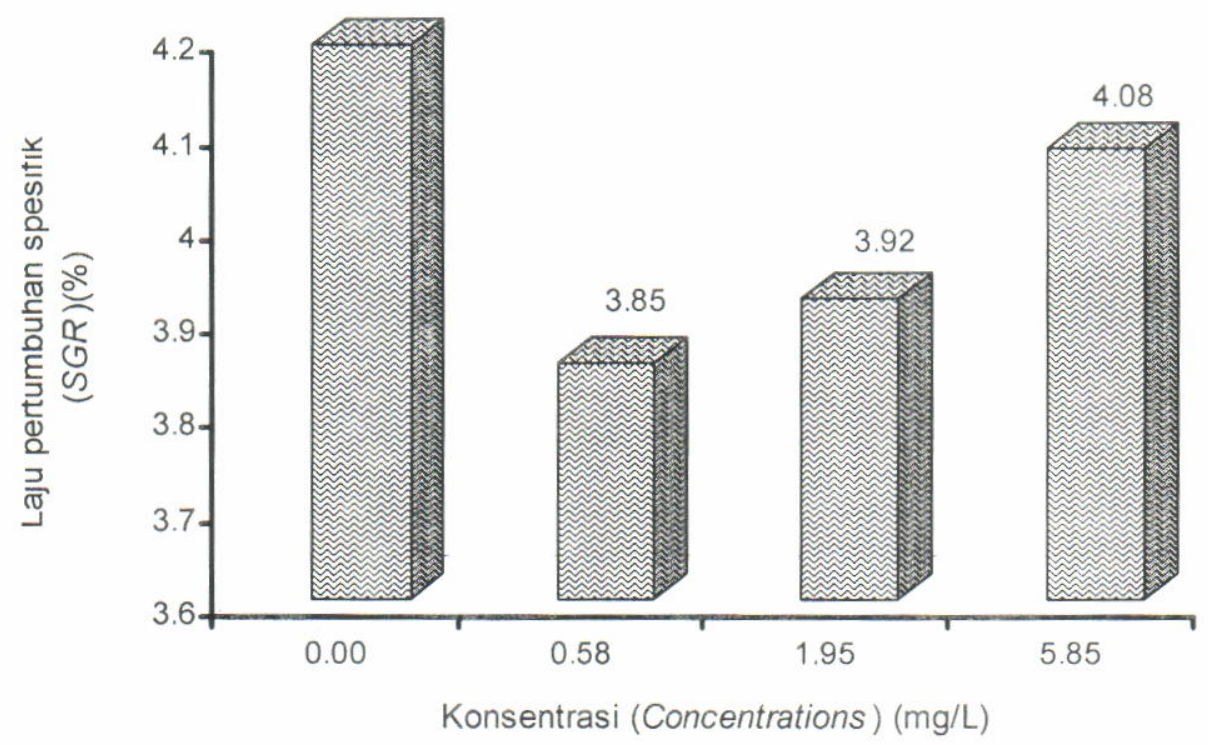

Gambar 4. Grafik laju pertumbuhan spesifik ikan sidat pada setiap konsentrasi perlakuan

Figure 4. Graphic of specific growth rate in each treatment

sidat yang telah terpapar selama 35 hari pada setiap konsentrasi perlakuan karena salah satu fungsi hati yang penting dalam kaitannya dengan pencemaran/ toksisitas di perairan menurut Lagler (1977) dalam Putranto (1994), adalah membantu proses pembuangan racun-racun dalam tubuh, sehingga dengan masuknya bahan toksik ke dalam tubuh ikan akan sangat berpengaruh terhadap fungsi dan struktur jaringan hati. Surfaktan AS yang larut dalam air akan masuk ke dalam hati ikan sidat bersama aliran darah sehingga akan mempengaruhi kinerja sel-sel hati (hepatosit) yaitu dalam proses sintesis, metabolic, dan ekskretorik.

Hasil pengamatan menunjukkan adanya gejala nekrosis pada jaringan hati dari ikan sidat yang dipaparkan dalam larutan surfaktan AS pada konsentrasi 1,95 mg/L dan 5,85 mg/L (Gambar 5). Nekrosis yang dialami jaringan hati ditandai dengan nukleus yang pecah berkeping-keping serta hancurnya kromatin menjadi serpihan yang tersebar ke dalam sel, menurut Thomas \& Richter (1984), kondisi ini merupakan nekrosis dengan tipe 
karioreksis. Nekrosis pada jaringan hati disebabkan oleh keracunan karena sifat toksik dari surfaktan AS pada konsentrasi $1,95 \mathrm{mg} / \mathrm{L}$ dan $5,85 \mathrm{mg} / \mathrm{L}$ selama 35 hari telah melebihi daya netralisir dan melampaui kapasitas fungsi hati sebagai organ yang membantu proses pembuangan racun dalam tubuh. Nekrosis karioreksis juga terjadi pada jaringan hati benih ikan mas (Nugraha, 2001) dan jaringan hati ikan rainbow trout (Takashima \& Hibiya, 1995) yang dipaparkan dalam larutan surfaktan AS pada konsentrasi subletal.

\section{Kualitas Air}

Untuk melihat kelayakan kualitas air pemeliharaan sebagai media penelitian, dilakukan pengukuran terhadap beberapa sifat fisika-kimia air, meliputi: suhu air, $\mathrm{pH}$, oksigen terlarut, $\mathrm{CO}_{2}$, alkalinitas, kesadahan, dan $\mathrm{N}-\mathrm{NH}_{3}$.

Dari Tabel 1 terlihat bahwa konsentrasi surfaktan AS tidak berpengaruh terhadap $\mathrm{pH}$ air penelitian dimana pada semua perlakuan nilainya sama dan

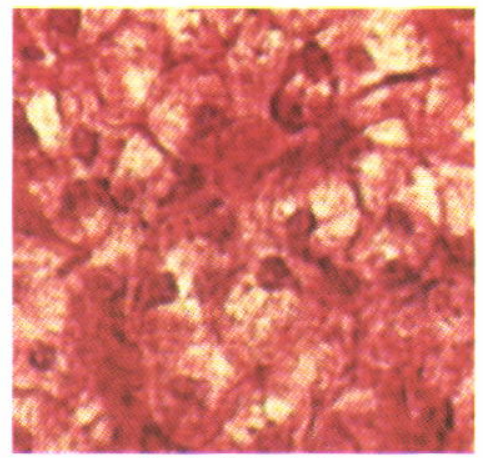

Kontrol (Control)

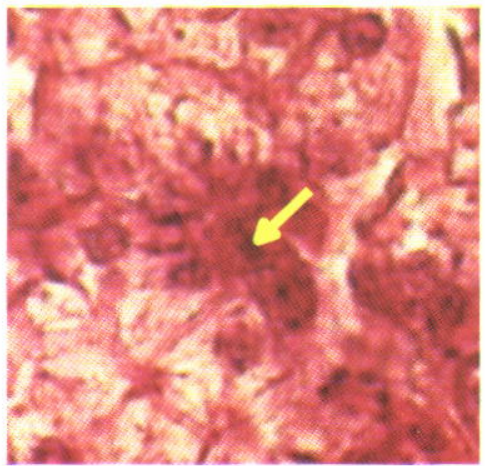

$(1.95 \mathrm{mg} / \mathrm{L})$

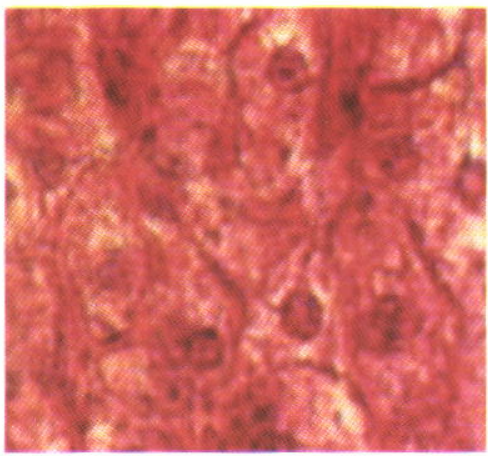

$(0.58 \mathrm{mg} / \mathrm{L})$

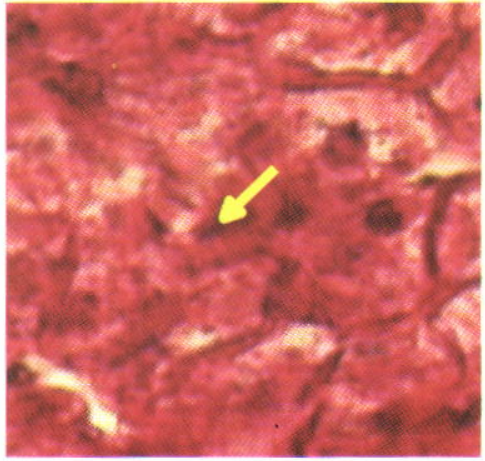

$(5.85 \mathrm{mg} / \mathrm{L})$

Gambar 5. Sel yang mengalami nekrosis pada hati ikan sidat Figure 5. Cell that experience necrosis in eel lever

Tabel 1. Data kisaran beberapa parameter fisika-kimia air pemeliharaan dari setiap perlakuan Table 1. Data of water quality in each treatment

\begin{tabular}{lcccc}
\hline \multirow{2}{*}{$\begin{array}{c}\text { Parameter } \\
\text { Parameter }\end{array}$} & \multicolumn{4}{c}{ Perlakuan surfaktan AS (Treatment of surfactant AS) (mg/L) } \\
\cline { 2 - 5 } & $\begin{array}{c}\text { Kontrol } \\
\text { Control }\end{array}$ & $\mathbf{0 . 5 8}$ & 1.95 & 5.85 \\
\hline $\mathrm{pH}$ & 7.5 & 7.5 & 7.5 & 7.5 \\
$\mathrm{O}_{2}(\mathrm{mg} / \mathrm{L})$ & $7.07--10.76$ & $7.05--9.97$ & $6.96--8.97$ & $6.27--8.08$ \\
$\mathrm{CO}_{2}(\mathrm{mg} / \mathrm{L})$ & $1.10--4.17$ & $1.10--5.50$ & $1.85--5.54$ & $1.10--4.80$ \\
$\mathrm{Alkalinitas}(\mathrm{mg} / \mathrm{L})$ & $71.80--71.84$ & $71.80--71.84$ & $71.80--71.84$ & $71.80--71.84$ \\
$\mathrm{Kesadahan}(\mathrm{mg} / \mathrm{L})$ & $73.60--76.20$ & $73.60--76.20$ & $73.60--76.20$ & $73.60--76.20$ \\
$\mathrm{~N}-\mathrm{NH}_{3}(\mathrm{mg} / \mathrm{L})$ & $0.001--0.010$ & $0.001--0.012$ & $0.001--0.013$ & $0.001--0.019$ \\
Suhu air $\left({ }^{\circ} \mathrm{C}\right)$ & $25--28$ & $25--28$ & $25--28$ & $25--28$ \\
\hline
\end{tabular}


stabil, yaitu 7,5. Surfaktan AS juga tidak berpengaruh terhadap $\mathrm{CO}_{2}$, alkalinitas, kesadahan, dan suhu air, terbukti dari hasil pengukuran dimana nilai parameter tersebut pada semua perlakuan relatif sama.

Kandungan oksigen terlarut dalam air dari semua perlakuan cukup baik. Kelarutan paling tinggi terdapat pada kontrol $(7,07-10,76 \mathrm{mg} / \mathrm{L})$ sedangkan yang paling rendah pada konsentrasi $5,85 \mathrm{mg} / \mathrm{L}(6,27-8,08$ $\mathrm{mg} / \mathrm{L}$ ). Jadi dapat disimpulkan bahwa semakin tinggi konsentrasi surfaktan AS dalam air maka kelarutan oksigen akan semakin rendah. Hal ini disebabkan perairan yang mengandung deterjen akan menghambat difusi $\mathrm{O}_{2}$ dari udara (Gameson, 1955 dalam Hynes, 1974).

Kandungan amoniak dalam air semakin meningkat dengan bertambahnya konsentrasi surfaktan AS. Peningkatan amonia disebabkan karena hasil ekskresi ikan yang semakin tinggi dengan bertambahnya konsentrasi polutan akibat dari metabolisme ikan yang semakin meningkat.

\section{KESIMPULAN}

Dari hasil percobaan dapat diambil kesimpulan sementara sebagai berikut:

- Kisaran toksisitas letal surfaktan AS terhadap benih ikan sidat adalah antara $9 \mathrm{mg} / \mathrm{L}$ sampai $35 \mathrm{mg} / \mathrm{L}$ dengan nilai $\mathrm{LC}_{50}-96$ jam sebesar $19,5 \mathrm{mg} / \mathrm{L}(18,26-$ $20,83 \mathrm{mg} / \mathrm{L})$.

- Semakin besar konsentrasi surfaktan AS dan semakin lama waktu pemaparan menyebabkan mortalitas ikan sidat semakin tinggi.

- Benih ikan sidat masih dapat mentolerir kandungan surfaktan AS dalam air sampai pada konsentrasi 5,85 $\mathrm{mg} / \mathrm{L}\left(30 \%\right.$ dari $\mathrm{LC}_{50}-96$ jam) meskipun dampak subletal dari konsentrasi tersebut dapat menyebabkan nekrosis karioreksis pada jaringan hati.

\section{DAFTAR PUSTAKA}

Abel, P.D. 1974. Toxicity of syntethic detergen to fish aquatic invertebrates. J. Fish. Biol,; 6: 279-298.

Affandi, R. dan U.M. Tang. 2002. Fisiologi Hewan Air. Unri Press, Pekanbaru-Riau, 213 pp.

Bathe, R.K. Sachsee, L. Ullman, W.D. Hormann, F. Zak, and R. Hess. 1974. The evaluation of fish toxicity in the laboratory. Excepta Medica, XVI: 113--124.

Belanger, S.E., E.M. Meiers, and R.G. Bausch. 1995. Direct and indirect ecotoxicological effect of Alkyl Sulfate and Alkyl Ethoxysulfate on macroinvertebrates in stream mecososms. Aquatic Toxicology no. 33. The Procter \& Gamble Company, Cincinnati, USA, p. 6587.

Bell, A.T. and D.V. Lighter. 1988. A handbook of normal shrimp histology. World Aquaculture Society. Baton Rouge, Lousiana, $150 \mathrm{pp}$.
Connel, D.W. and G.J. Miller. 1995. Kimia dan Ekotoksikologi Pencemaran. (Terjemahan Y. Koestoer). Universitas Indonesia. Jakarta, 520 pp.

Effendie, M.I. 1979. Metoda Biologi Perikanan. Yayasan Agromedia. Bogor, 112 pp.

Huet, A.G. 1987. Water Pollution and Fish Physiology. Depart. of Biology, Virginia Politechnic Institute and State University. C\&C Press, In. Florida, USA, p. 31219.

Hynes, H.B.N. 1974. The Ecology of Running Water. Univ. Toronto Press. Canada, $555 \mathrm{pp}$.

Kartz, M. 1971. The effect of pollution upon aquatic life. In L.L. Claccio eds. Water and Water Pollution Handbook. Vol I. Marcel Dekker Inc. New York, p. 297328.

Kent, J.A. 1992. Riegel's: Handbook of Industrial Chemistry $9^{\text {th }}$. Eds. Van Nostrand Reinold, New York.

Koesoemadinata, S. 1982. Lethal toxicity of 24 insecticides formulation commonly use for rice pest control in irrigated rice fields, to two Indonesian freshwater fish species Cyprinus carpio and Puntius javanicus. Bull. Pen. Per., 2(1): 82--87.

Litchfield, Jr.J.T., and F. Wilcoxon. 1949. A simplifield method of evaluation dose-effect experiments. $J$. Phar. Exp. Therap., 56: 89-113.

Maeiw, A. 1971. The Pollution of Water by Detergen. OECD Publications. Paris, Frence, $86 \mathrm{pp}$.

Metelev, V.V., A.I. Kanaev, and N.G. Dzasokhava. 1971. Water Toxicology. Amerind Publishing, Co. PVT Ltd. New York, p. 150--155.

Nontji, A. 1987. Laut Nusantara. Djambatan Press, 368 pp.

Nugraha, D.M. 2001. Pengaruh Surfaktan Detergen Alkyl Sulfate (AS) terhadap Larva-Juvenil Ikan Mas (Cyprinus carpio Linn.). Skripsi. Fakultas Perikanan dan Ilmu Kelautan. IPB, 66 pp.

Owen, O.S. 1975. Natural resources conservation. An ecological approach: Water Pollution. Second ed. Macmillan Pulb. Co. Inc. New York, USA, 474 pp.

Pong-Masak, P.R. 2003. Toksisitas Akut, Biokonsentrasi dan Bioeliminasi serta Waktu Paruh Insektisida Triklorfon pada Udang Windu, Penaeus monodon. Thesis. Program Pascasarjana, IPB, $66 \mathrm{pp}$.

Putranto, D.I. 1994. Toksisitas dan Pengaruh Subletal Ammonium Sulfat terhadap Struktur Branchia, Hepar serta Pertumbuhan Ikan Karper (Cyprinus carpio L.). Fakultas Biologi - UGM. Yogyakarta, 59 pp.

Ricker, W.E. 1975. Computation and interpretation of biological statistic of fish population. Bull. Fish. Res. Board Can, p. 119-382.

Takashima, F. dan T. Hibiya. 1995. An atlas of fish histology. Normal and Pathologycal Features. $2^{\text {nd }}$ ed. Kodansha, Tokyu, 195 pp.

Tanjung, P. 1982. The Acute Toxicology and Histopatology of Brook Trout (Salvelinus Frontalis Exposed) to Aluminium in Acid Water. Fordan University. New York, 87 pp.

Thomas, C. dan G.W. Richter. 1984. Sandritter's color atlas texbook of histopathology. Seventh editio. Year Book Medical Publisher, Inc., 363 pp. 
Wilbert, C.E. 1971. The Biologycal Aspect of Water Pollution. Charles, C. Thomas Publisher. Springfield, Illiois, USA, 294 pp.
Zonneveld, N.E.A., Huisman, dan J.H. Boon. 1991. Prinsip-Prinsip Budi Daya Ikan (Terjemahan) Gramedia Pustaka Utama. Jakarta, 318 pp. 
